\title{
Isoflavone Extracts Enhance the Effect of Epidermal Growth Factor Receptor Inhibitors in NSCLC Cell Lines
}

\author{
RITA AMBROSIO $^{1 *}$, MARIA NEVE OMBRA $^{2 *}$, CESARE GRIDELLI $^{1}$, \\ GIANLUCA PICARIELLO ${ }^{2}$, MICHELE DI STASIO ${ }^{2}$ and MARIA G. VOLPE ${ }^{2}$ \\ ${ }^{1}$ Division of Medical Oncology, S.G. Moscati Hospital, Avellino, Italy; \\ ${ }^{2}$ Institute of Food Sciences, National Research Council, Avellino, Italy
}

\begin{abstract}
Aim: We investigated the effects of the pharmacological inhibition in vitro of epidermal growth factor receptor (EGFR) in combination with isoflavones. Materials and Methods: Four anticancer drugs (erlotinib, gefitinib, afatinib and AZD9291) were combined with soy and red clover isoflavone extracts and used in cellular proliferation assays. The antitumor activity of inhibitors alone and in combination with isoflavone extracts was compared on three non-small cell lung cancer (NSCLC) cell lines with affiant EGFR genotype: A549 (EGFR wt); H1795 (EGFR T790M); HCC827 (EGFR del E746-A750). Results: Combined treatment with extracts significantly enhanced the antiproliferative activity of all inhibitors against these cell lines. Bioactive compounds of extracts may synergize the antitumor efficacy of the inhibitors. Conclusion: To date, as far as we are aware, this is the first report of the combined effect of isoflavone extracts and EGFR inhibitors on human NCSLC cell growth. Sequential treatment with these drugs combined with isoflavones may represent the basis for a new therapeutic approach.
\end{abstract}

Epidermal growth factor receptor (EGFR)-targeted therapies using small molecules, such as tyrosine kinase inhibitors (TKI) have recently been approved for non-small cell lung cancer (NSCLC). In particular, two EGFR tyrosine kinase inhibitors (TKI), gefitinib (ZD1839, Iressa) and erlotinib (OSI774, Tarceva), represent the first generation of molecular-targeted agents developed for the treatment of

*These Authors contributed equally to this study.

Correspondence to: Dr Maria Grazia Volpe, Institute of Food Sciences - CNR, Via Roma, 64, 83100 Avellino, AV, Italy. Tel: +39 0825299411, Fax: +39 0825781585, e-mail: mgvolpe@isa.cnr.it

Key Words: Isoflavones, non-small cell lung cancer, antiproliferative activity, tyrosine kinase inhibitors.
NSCLCs (1-3). Irreversible inhibitors such as afatinib and AZD9291 constitute second- and third-generation EGFR inhibitors. Progression-free survival (PFS) of patients with EGFR mutation receiving gefitinib, erlotinib or afatinib is improved when compared with standard chemotherapy, as demonstrated with randomized trials (4). Unfavorably, TKI therapies may become ineffective due to acquired resistance that may develop after a duration of response of $\sim 10$ months up to 1 year $(5,6)$. A secondary mutation in exon 20 of EGFR within the residue at position 790 inducing a threonine to methionine substitution (T790M) was determined as the first cause of resistance identified on a genetic basis. T790M causes resistance through changes in adenosine triphosphate (ATP) affinity because T790M mutation restores the ATP affinity of the kinase, reestablishing ATP as the favored substrate rather than the administered TKI (7). Second-generation EGFR TKIs, such afatinib, form irreversible covalent bonds with EGFR and are potentially effective in vitro against cells with EGFR T790M. Third-generation EGFR TKIs, such as AZD9291/are being developed to overcome resistance to first- and secondgeneration EGFR TKIs. In preclinical studies, AZD9291 was active both in vitro and in vivo against cell lines and murine models harboring the EGFR T790M mutation (8). Very promising results from an ongoing phase I study on AZD9291 have been reported (9).

Recently, natural dietary compounds have captured attention because of their synergistic effects with anticancer drugs against various types of cancer. Natural phytochemicals may accomplish their antitumoral effect through targeting diverse cancer cell signaling pathways, giving rise to cell-cycle block and apoptosis, or regulating antioxidant status and detoxification (10). Much evidence has shown that isoflavones exert their pleiotropic effects on cancer cells by interfering in cellular signaling pathways including nuclear factor kappa-light-chain-enhancer of activated B-cells, serine/threonine kinase, mitogen-activated protein kinase, and $\mathrm{p} 53$. 
Isoflavones are principally recovered in members of the Leguminosae family (11). Genistein is the most extensively analyzed flavonoid, it is involved in numerous biological actions with potential beneficial effects, rightly becoming a focus for research (12). Genistein is also a well-known TKI and induces apoptosis in several types of cancer, such as lymphoma, leukemia, breast, prostate, head and neck, pancreatic and lung cancer (13).

In the present study, the effect of gefitinib, erlotinib, afatinib and AZD9291 (selective EGFR TKIs) combined with isoflavones from soy and red clover was assayed on a panel of NSCLC cell lines by using 3-(4,5-dimethylthiazol2-yl)-2,5-diphenyltetrazolium bromide (MTT) and crystal violet assays. Our aim was to evaluate in vitro whether these isoflavone extracts synergize with TKIs to inhibit NSCLC cell growth.

\section{Materials and Methods}

Samples and extraction. Fresh faba beans (Vicia faba), peas (Pisum sativum), ordinary beans (Phaseolus vulgare) and soybean (Glycine max) seeds were purchased at a local market, while dried red clover (Trifolium pretense L.) was obtained at a herbalist's shop. Standards of genistin, glycitin, daidzin, biochanin A and formonotenin were purchased from Sigma-Aldrich (St. Louis, MO, USA). Genistein, glycitein and daidzein aglycones were obtained by acid hydrolysis (using $3.4 \mathrm{~N} \mathrm{HCl}$ at $50^{\circ} \mathrm{C}$ for $200 \mathrm{~min}$ ) of the corresponding $\beta$ glucosides, according to Chiang et al. (14), with slight modifications.

A protocol for the extraction of phenolic compounds was adapted from Rostagno et al. (15). Briefly, $0.5 \mathrm{~g}$ of the dry sample was suspended in $5 \mathrm{ml}$ of $50 \%$ ethanol $(\mathrm{v} / \mathrm{v})$ and ultrasonicated for 20 $\min$ at $60^{\circ} \mathrm{C}$. The suspension was centrifuged for $10 \mathrm{~min}$ at $\sim 2500 \times \mathrm{g}$ and the supernatant was recovered. The pellet was re-extracted for 12 hours with an additional $5 \mathrm{ml}$ of solvent and centrifuged. The two supernatants were combined and stored in a freezer at $-20^{\circ} \mathrm{C}$ for subsequent analysis $(16,17)$.

Determination of total phenolic compounds. The total polyphenol content in the extracts was determined using the Folin-Ciocolteau method (18). Fifty microliters of dried bean, pea, red clover and soya extracts were combined to $3 \mathrm{ml}$ with distilled water, $250 \mu \mathrm{l}$ of Folin and $750 \mu \mathrm{l}$ of $7 \%(\mathrm{w} / \mathrm{v}) \mathrm{Na}_{2} \mathrm{CO}_{3}$. After $8 \mathrm{~min}, 950 \mathrm{ml}$ of distilled water was added. Samples were left for $2 \mathrm{~h}$ at room temperature in the dark and the absorbance at $765 \mathrm{~nm}$ was then determined spectrophotometrically microplate reader, (Cary 50 MPR; Varian, LAB X, LA Jolla, CA, USA). Total polyphenol content was expressed as gallic acid equivalents (GAE, in $\mathrm{mg}$ ) per gram of dry material.

Determination of total flavonoid compounds. Total flavonoid content was determined using the aluminium chloride colorimetric assay (19). Briefly, $50 \mu \mathrm{l}$ of extracts or standard solution of catechin $(6.25,12.5,25,50,100 \mu \mathrm{g} / \mathrm{ml})$ in $80 \%$ ethanol was added to $10 \mu \mathrm{l}$ of $10 \%(\mathrm{w} / \mathrm{v})$ aluminium chloride solution, followed by the addition of $150 \mu \mathrm{l}$ of $95 \%$ ethanol. Ten microliters of $1 \mathrm{M}$ sodium acetate was added to each test sample in a 96-well plate. The absorbance was measured at $510 \mathrm{~nm}$ with a microplate reader (Biotek, San Jose,
CA, USA). Total flavonoid content was expressed as mg catechin equivalents (CAE, in $\mathrm{mg}$ ) per gram of dry material. All samples were analyzed in triplicates.

Determination of antioxidant activity. The 2,2-diphenyl-1picrylhydrazyl (DPPH) free radical-scavenging activity assay was performed as described by Rostagno et al. (15). Briefly $20 \mu \mathrm{l}$ of extract $(1 \mathrm{mg} / \mathrm{ml})$ in absolute ethanol was added to $180 \mu \mathrm{l}$ of DPPH reagent in a 96-well plate. The absorbance was measured at $517 \mathrm{~nm}$ after $90 \mathrm{~min}$, with a microplate reader (Biotek). Experiments were performed in triplicates. The results were expressed as percentage inhibition (I\%), which was calculated using the following formula:

$\mathrm{I} \%=\left[\left(\mathrm{A}_{\mathrm{DPPH}}-\mathrm{A}_{\text {Sample }}\right) / \mathrm{A}_{\mathrm{DPPH}}\right] \times 100$

where: $\mathrm{A}_{\mathrm{DPPH}}$ is the absorbance of the control DPPH at time $\mathrm{t}=0$, and

$\mathrm{A}_{\text {Sample }}$ is the absorbance of the sample after time $t=90$ '.

High-performance liquid chromatography (HPLC) analysis of isoflavones. Isoflavone extracts were analyzed using a modular HPLC system (1100 Series; Agilent Technology, Palo Alto, CA, USA) equipped with a $250 \times 2.0 \mathrm{~mm}, 4 \mu \mathrm{m}$ particle diameter, Jupiter ${ }^{\circledR} \mathrm{C} 18$ reversed-phase column (Phenomenex, Torrance, CA, USA) that was maintained at $37^{\circ} \mathrm{C}$ in a thermostatic oven. Separations were carried out at a $0.2 \mathrm{ml} / \mathrm{min}$ constant flow rate, applying a 5-65\% linear gradient of eluent B (acetonitrile $/ 0.1 \%$ trifluoroacetic acid) in $60 \mathrm{~min}$, following $5 \mathrm{~min}$ of isocratic elution at $5 \% \mathrm{~B}$. Eluent $\mathrm{A}$ was $0.1 \%$ trifluoroacetic acid in HPLC-grade water. A diode array detector was used to record UV-Vis spectra every $2 \mathrm{~s}$ in the 190-650 $\mathrm{nm}$ range. The HPLC separations were monitored recording at the following wavelengths: $\lambda=254,280,320$ and $360 \mathrm{~nm}$; and elaborated with the HPLC ChemStation software vers. A.07.01 (Agilent Technology) furnished with the chromatographer.

Cell culture. Three NSCLC cell lines with different EGFR mutation status and sensitivity to EGFR TKIs were used: HCC827 (del E746A750), NCI-H1975 (T790M), and A549 (wild-type). Cells were obtained from the American Type Culture Collection (ATCC; Manassas, VA, USA) and maintained in ATCC-specified growth medium.

EGFR inhibitors. Erlotinib and gefitinib were purchased from Genentech (South San Francisco, CA, USA); AstraZeneca (London, UK) commercial suppliers, respectively. Afatinib was provided by Boehringher Ingelheim (Ingelheim Am Rhein, Rheinland-Pfalz, Germany), AZD9291 by AstraZeneca. Stock solutions of TKIs were prepared in dimethyl sulfoxide at a concentration of $10 \mathrm{mmol} / \mathrm{l}$ and maintained at $-20^{\circ} \mathrm{C}$. Drugs were diluted to $1 \mathrm{mmol} / 1$ in $50 \%$ ethanol for a working solution.

Measure of cellular viability by 3-(4,5-dimethylthiazol-2-yl)-2,5diphenyltetrazolium bromide (MTT) assay. The three NSCLC cell lines were seeded at a density of 3,000 cells/well in 96-well plates for $24 \mathrm{~h}$. After $24 \mathrm{~h}$, the cells were incubated with different concentrations of inhibitors $(2.5 \mathrm{nM}$ to $15 \mu \mathrm{M}$ based on cell line sensitivity). The effects of each drug alone and the combination of drug and extracts for $48 \mathrm{~h}$ were assayed. Cell survival was determined by a standard MTT assay by the addition of $20 \mu \mathrm{l}$ of 
MTT (Promega CellTiter $96^{\circledR}$ AQueous One Solution Cell; Promega, Madison, WI, USA) for $2 \mathrm{~h}$. The color intensity was measured by microplate reader (Cary $50 \mathrm{MPR}$; Varian) at $412 \mathrm{~nm}$. Wells containing cells without any treatment were used as positive controls and the OD value was used to represent $100 \%$ cellular viability.

The half-maximal inhibitory concentration $\left(\mathrm{IC}_{50}\right)$ values were determined by ED50plus v1.0 online software, (Tlalpan, Mexico DF, Mexico). Results represent the median of three separate experiments each conducted in triplicate.

Crystal violet assay. Cells were seeded at 3,000 per well in 96-well plates. Twenty-four hours after seeding, cells were exposed to drugs with/without extracts as described above. Forty-eight hours after treatment, cells were fixed with formaldehyde and stained with $0.01 \%$ crystal violet for $15 \mathrm{~min}$ at room temperature. Stained cells were washed with phosphate-buffered saline. Viability was determined by measuring the absorbance at $595 \mathrm{~nm}(20)$.

Statistical analysis. ANOVA tests were used for statistical evaluation of results in three independent replications. Values of $p$ lower than 0.05 were considered significant.

\section{Results and Discussion}

Isoflavone extracts. Isoflavones, a subclass of the flavonoids, are non-nutrient plant compounds, which occur predominantly as $\beta$-glucosides (genistin, daidzin, glycitin), or as acetyl- $\beta$ glucosides and malonyl- $\beta$-glucosides, and are therefore polar, water-soluble compounds $(21,22)$. Precursors of daidzein and genistein, and especially the 4'-methyl ethers formononetin and biochanin A, respectively, are mainly found in red clover (23).

Like soy, red clover contains the isoflavones genistein, daidzein, biochanin $\mathrm{A}$, and formononetin; however, soy contains higher amounts of genistein and daidzein, while the dominant isoflavones in red clover are biochanin $\mathrm{A}$ and formononetin (24-27).

Solvent extraction is the most frequently used technique to obtain crude extracts from matrices of vegetable origin. The most common solvents employed are water, ethanol, acetone and acetic acid, used pure or in a mixture (16). It is known that the amount of extractable substances in the course of an extraction with solvents depends both on the peculiarities of the raw vegetable material and the solvent used (28). Clearly, for each specific plant matrix, there is a need to test and select the solvent and the most suitable conditions for maximizing the extraction yield and antioxidant activity of the extracts obtained (29-31). For soybean, extraction with acetone/acetic acid was more efficient, while for red clover, extraction with ethanol provided the best yield for the extract.

Total polyphenols, flavonoid content and antioxidant activities of the extracts from peas, fava beans, beans, soybean seeds and red clover were determined as reported in Table I. The content of phenolic compounds was found to range from $1.5 \mathrm{mg} / \mathrm{g}$ GAE for beans to $130 \mathrm{mg} / \mathrm{g} \mathrm{GAE}$ for
Table I. Total polyphenol and flavonoid content, and antioxidant activity of the extracts from peas, fava beans, beans, soybean seeds and red clover.

\begin{tabular}{lccc}
\hline Dried sample & $\begin{array}{c}\text { Total phenols } \\
(\mathrm{mg} \mathrm{GAE} / \mathrm{g})\end{array}$ & $\begin{array}{c}\text { Total flavonoids } \\
(\mathrm{mg} \mathrm{CAE} / \mathrm{g})\end{array}$ & $\begin{array}{c}\text { Inhibition } \\
(\%)^{*}\end{array}$ \\
\hline Soybean & 26.40 & 17.60 & 60 \\
Fava bean & 37.03 & 28.52 & 85 \\
Pea & 1.50 & 0.04 & 30 \\
Bean & 1.64 & 0.13 & 60 \\
Red clover & 130.00 & 71.00 & 88 \\
\hline
\end{tabular}

GAE: Gallic acid equivalent; CAE: catechin acid equivalent. *By free radical-scavenging activity assay.

red clover, while total flavonoids ranged from $0.4 \mathrm{mg} / \mathrm{g} \mathrm{CAE}$ for peas to $71 \mathrm{mg} / \mathrm{g} \mathrm{CAE}$ for red clover.

The radical-scavenging properties reported as $\% \mathrm{DPPH}^{\bullet}$ inhibition ranged from 30 to $88 \%$, the highest being that for red clover extract. Thus, total phenolics, total flavonoids and antioxidant potential determined as radical-scavenging property were roughly correlated.

HPLC analysis of isoflavone extracts. The expected isoflavones both in the glycoside and aglycone forms were detected in the HPLC chromatogram of the ethanolic extracts of soybean flour (Figure 1A). Isoflavone components were assigned on the basis of the retention time $\left(t_{r}\right)$ and $U V$ spectral properties, also in comparison to those of the standards. Acetyl and malonyl derivatives were identified through the elution order, by comparison with literature data (32). Isoflavones were also monitored in the extracts from other legumes, including faba beans, peas and ordinary beans. Considering its well-established pseudo-estrogenic properties, red clover (Trifolium pratense) was monitored for the occurrence of isoflavones. The HPLC chromatogram of the ethanolic extracts from dried red clover is shown in Figure 1B. Along with minor peaks corresponding to the isoflavone components detected in soy, red clover exhibited dominant peaks at longer $\mathrm{t}_{\mathrm{r}}$. By comparison with literature data (33) and on the basis of the UV-Vis spectra, these components were identified as formonotenin $\left(\mathrm{t}_{\mathrm{r}} 49.9 \mathrm{~min} ; \lambda_{\max } 260,300 \mathrm{~nm}\right)$ and biochanin $\mathrm{A}\left(\mathrm{t}_{\mathrm{r}} 60.1 \mathrm{~min} ; \lambda_{\max } 248 \mathrm{~nm}\right)$. Analogously to soy, red clover isoflavones can occur also as acetyl- and malonyl-glucoside derivatives (34). These components are most likely the minor peaks with $t_{r}$ in the 35-46 range, showing UV spectra characteristic of formonotenin and biochanin A. A number of additional metabolites structurally related to isoflavones have been described (33). However, a definitive characterization of these species would require the application of complementary analytical techniques. On the 

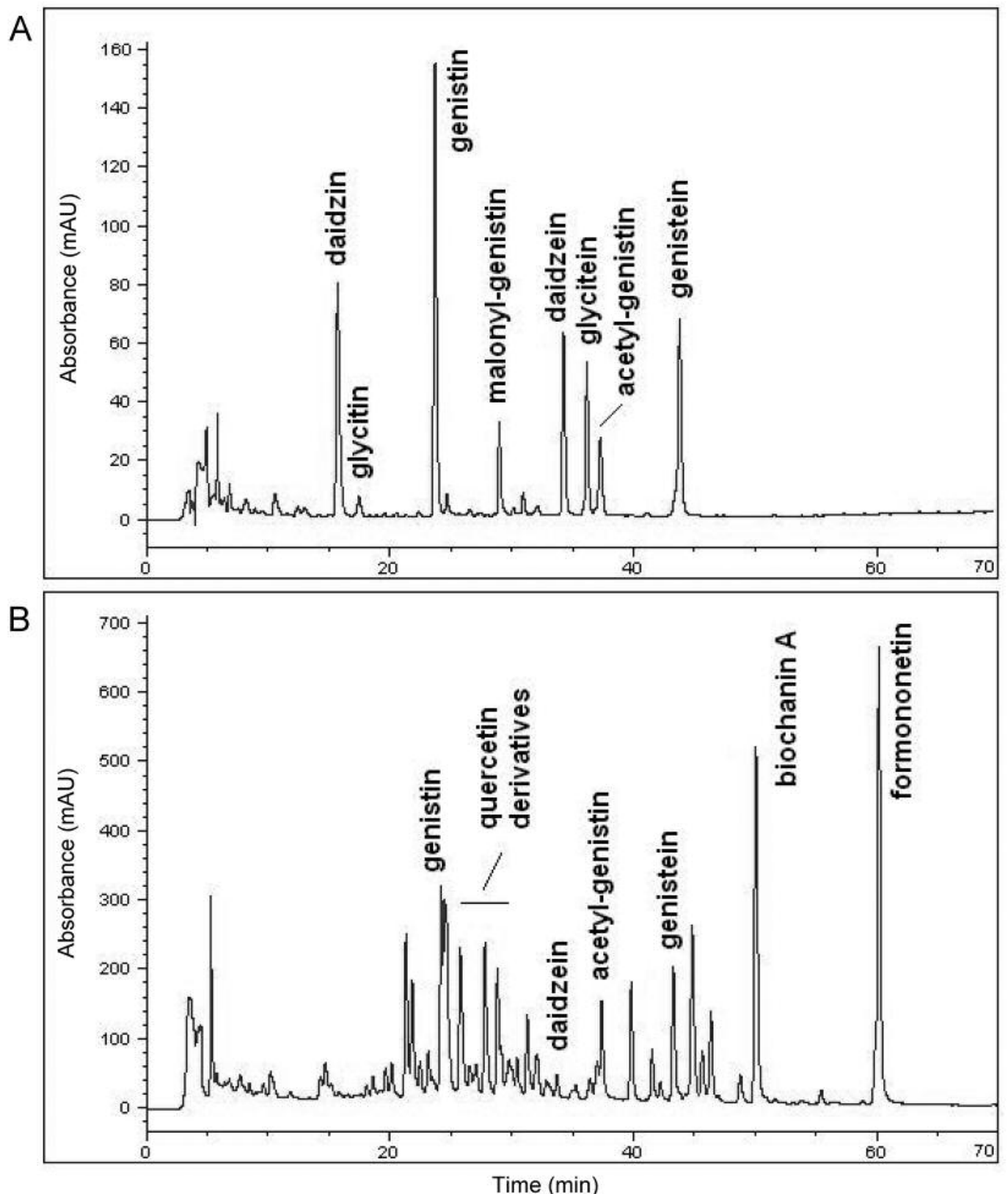

Figure 1. Reversed-phase high-performance liquid chromatography chromatograms of isoflavones from soy (A) and red clover (B) acquired at $\lambda=254 \mathrm{~nm}$. The main isoflavone components were assigned by spectrophotometric analysis using a diode array detector and comparison with individual standards.

other hand, the HPLC peaks at $\mathrm{t}_{\mathrm{r}} 20-35$ min were members of different metabolite classes and included flavonols such as quercetin glucoside and quercetin rutinoside (rutin) showing characteristic absorption bands with $\lambda_{\max }=355-360 \mathrm{~nm}$.

Induction of growth inhibition by erlotinib, gefitinib, afatinib and AZD9291. The viability of A549, HCC827 and H1975 cell lines treated with gefitinib, erlotinib, afatinib and
AZD9291 was determined by the MTT assay. Both erlotinib, gefitinib, afatinib and AZD9291 demonstrated growth inhibition of all three cell lines, but the sensitivity of the cell lines varied markedly. HCC 827 cells with mutation in the EGFR gene, (del E746-A750) were highly sensitive to gefitinib and erlotinib at low nanomolar concentrations. A549 cells with wild-type EGFR were sensitive only at higher concentrations of EGFR TKIs $(>9 \mu \mathrm{M})$, while H1975 cells 
were sensitive only at maximum concentrations $(>20 \mu \mathrm{M})$. Likewise for the irreversible inhibitors afatinib and AZD9291, we observed that $\mathrm{HCC} 827$ cells were the most responsive of the three cell lines, and $\mathrm{H} 1975$ was more responsive to AZD9291 than to afatinib $\left(\mathrm{IC}_{50}=4.2 \mu \mathrm{M} v s .12 \mu \mathrm{M}\right.$, respectively). After $48 \mathrm{~h}$ of treatment, growth of cells was significantly inhibited in a dose-dependent manner and for each inhibitor, an $\mathrm{IC}_{50}$ value was calculated from the doseresponse curves of the NSCLC cell lines. In Table II, $\mathrm{IC}_{50}$ values for TKI against the three cell lines are reported.

Soy and red clover isoflavones alone did not exhibit significant growth inhibition. Neither soy nor red clover extracts had any significant inhibitory effect against all three cell lines, although a trend indicating a reduction of vitality was found at increasing doses $(p>0.05)$. An indicative, albeit weak, inhibitory effect was observed for HCC827 cells at the highest concentration, not significant in any case $(p>0.05$ data not shown).

Effects of gefitinib alone and in combination with extracts on A549, HCC827 and H1975 cell proliferation. To evaluate the effect of GEFITINIB alone and in combination with extracts on the cell viability of A549, HCC827 and H1975 cells in vitro, crystal violet assays were performed for $48 \mathrm{~h}$. Concentrations above $200 \mu \mathrm{g} / \mathrm{ml}$ of isoflavones, resulted in a marked reduction in cell viability when used in combination with gefitinib.

It was found that the inhibitory rates with gefitinib alone, and in combination with extracts, were higher compared with the control group $(p<0.01)$. There was no significance difference in vitality between cells treated with the extracts alone and control groups $(p>0.05)$. However, the inhibitory rate in the group treated with gefitinib in combination with soy or red clover extract was higher compared with the agent alone ( $p<0.05$; Table III). The induction of growth inhibition by gefitinib in combination with red clover extract was higher than that observed with soy extract, although not significantly.

The $\mathrm{IC}_{50}$ value $(230 \mathrm{nM})$ calculated for gefitinib alone was reduced (135 $\mathrm{nM})$ in the presence of soy extract and in combination with red clover extract $(100 \mathrm{nM})$ for the HCC827 cell line.

The combination of isoflavone extracts and gefitinib showed the highest levels of cytotoxicity, with inhibitory concentration $\mathrm{IC}_{50}$ values at $13.47 \mu \mathrm{M}$ and $12.9 \mu \mathrm{M}$ for the A549 cell line, respectively, with soy and red clover extracts, in corresponding order, as compared with drug alone: $\mathrm{IC}_{50}$ value of $18.6 \mu \mathrm{M}$.

Ultimately, even for the H1975 cell line carrying the mutation which confers drug resistance, the $\mathrm{IC}_{50}$ value calculated for the drug alone $48.5 \mu \mathrm{M}$ was reduced to $42 \mu \mathrm{M}$ and $31 \mu \mathrm{M}$ when the drug was given in combination with soy and red clover extract, respectively.
Table II. Half-maximal inhibitory concentration $\left(I C_{50}\right)$ values for tyrosine kinase inhibitors against three cell lines.

\begin{tabular}{lcccc}
\hline & \multicolumn{4}{c}{ Median $\mathrm{IC}_{50} \pm \mathrm{SD}$} \\
\cline { 2 - 5 } Cell line & Gefitinib & Erlotinib & Afatinib & AZD9291 \\
\hline HCC827 & $230.0 \pm 1.9 \mathrm{nM}$ & $70.0 \pm 2.2 \mathrm{nM}$ & $132.0 \pm 0.4 \mathrm{nM}$ & $512.0 \pm 1.5 \mathrm{nM}$ \\
A549 & $18.6 \pm 1.4 \mu \mathrm{M}$ & $9.2 \pm 0.1 \mu \mathrm{M}$ & $11.0 \pm 0.4 \mu \mathrm{M}$ & $8.4 \pm 0.2 \mu \mathrm{M}$ \\
$\mathrm{H} 1975$ & $48.5 \pm 2.8 \mu \mathrm{M}$ & $24.8 \pm 1.1 \mu \mathrm{M}$ & $12.0 \pm 0.2 \mu \mathrm{M}$ & $4.2 \pm 0.7 \mu \mathrm{M}$ \\
\hline
\end{tabular}

SD: Standard deviation.

Effects of erlotinib alone and in combination with extracts on NSCLC cell lines. In accordance with the results obtained with gefitinib, $\mathrm{HCC} 827$ cells were highly sensitive to erlotinib $\left(\mathrm{IC}_{50}=70 \mathrm{nM}\right)$, whereas A549 cells were on average sensitive $\left(\mathrm{IC}_{50}=9.2 \mu \mathrm{M}\right)$ and $\mathrm{H} 1975$ cells were scarcely responsive $\left(\mathrm{IC}_{50}=24.8 \mu \mathrm{M}\right)$. Due to the presence of the T790M mutation, which confers resistance to treatment with TKI inhibitors, H1975 required a higher concentration of inhibitor compared to the HCC827 and A549 cell lines.

We observed a reduction of the $\mathrm{IC}_{50}$ values for all three cell lines when erlotinib was used in combined treatments with isoflavones of soy or red clover. Table III reports all the $\mathrm{IC}_{50}$ values.

Effects of afatinib alone or in combination with extracts on cellular viability. Dose-response curves for afatinib and extracts were generated for the sensitive EGFR mutant and wild-type NSCLC cell lines.

The $\mathrm{IC}_{50}$ values for afatinib combined with soy or red clover extracts were calculated. HCC827 cells were more responsive to afatinib compared with A549 cell line, while H1975 was the least responsive. For all the cell lines investigated, we observed an enhanced inhibitory effect when TKIs were used in combination with soy or red clover extracts (Table IV).

Inhibition by AZD9291 irreversible TKI alone and in the presence of isoflavones. Treatment with AZD9291, a thirdgeneration irreversible EGFR TKI, as single agent for $48 \mathrm{~h}$ resulted in a dose-dependent inhibition of growth for HCC827, A549 and $\mathrm{H} 1975$ cell lines. The $\mathrm{IC}_{50}$ values for AZD9291 alone and in combination with soy or red clover extracts were compared for the three cell lines (Table IV). Soy and red clover extracts markedly synergized AZD9291induced cell death, both in HCC827 and H1975, as well as in NSCLC cells with wild-type EGFR (A549).

\section{Conclusion}

Soy and red clover extracts enriched in isoflavones enhanced cell growth inhibition induced by erlotinib, gefitinib, afatinib, and AZD9291. Most likely related to its high 
Table III. Half-maximal inhibitory concentration $\left(I_{50}\right)$ values for gefitinib and erlotinib, alone and with soy or red clover extract, against three cell lines.

\begin{tabular}{lcccccc}
\hline & \multicolumn{4}{c}{ Median $\mathrm{IC}_{50} \pm \mathrm{SD}$} \\
\cline { 2 - 7 } Cell line & Alone & + Soy extract & + Red clover extract & Alone & Erlotinib \\
\cline { 2 - 8 } HCC827 & $230.0 \pm 1.9 \mathrm{nM}$ & $135.0 \pm 6.8 \mathrm{nM}$ & $100.0 \pm 5.1 \mathrm{nM}$ & $70.0 \pm 2.2 \mathrm{nM}$ & $38.0 \pm 3.4 \mathrm{nM}$ & $36.0 \pm 2.3 \mathrm{nM}$ \\
A549 & $18.6 \pm 1.4 \mu \mathrm{M}$ & $13.5 \pm 0.7 \mu \mathrm{M}$ & $12.9 \pm 0.2 \mu \mathrm{M}$ & $9.2 \pm 0.1 \mu \mathrm{M}$ & $5.8 \pm 0.4 \mu \mathrm{M}$ & $5.3 \pm 0.4 \mu \mathrm{M}$ \\
$\mathrm{H} 1975$ & $48.5 \pm 2.8 \mu \mathrm{M}$ & $42.0 \pm 2.0 \mu \mathrm{M}$ & $31.0 \pm 2.0 \mu \mathrm{M}$ & $24.8 \pm 1.1 \mu \mathrm{M}$ & $21.7 \pm 0.3 \mu \mathrm{M}$ & $20.2 \pm 0.9 \mu \mathrm{M}$ \\
\hline
\end{tabular}

SD: Standard deviation.

Table IV. Half-maximal inhibitory concentration $\left(I_{50}\right)$ values for afatinib and AZD9291, alone and combined with soy or red clover extract, against three cell lines.

\begin{tabular}{lcccccc}
\hline & \multicolumn{5}{c}{ Median $\mathrm{IC}_{50} \pm \mathrm{SD}$} \\
\cline { 2 - 7 } Cell line & Alone & + Soy extract & + Red clover extract & Alone & AZD9291 \\
\cline { 2 - 7 } & & & & \\
\hline
\end{tabular}

SD: Standard deviation.

isoflavone content, red clover extract was the most effective. Soy and red clover isoflavones in combination with TKI could represent a potential treatment to contribute to arresting tumor growth or to reducing the doses of the chemotherapeutics in the treatment of NSCLC.

As far as we are aware, this is the first report on the inhibitory effect of isoflavone extracts and AZD9291 on NSCLC cell growth.

Further studies are required to elucidate the mechanisms and to confirm the anticancer synergistic activity of TKIisoflavones in vivo.

\section{References}

1 Hynes NE and Lane HA: ERBB receptors and cancer: the complexity of targeted inhibitors. Nature Rev Cancer 5: 341$354,2005$.

2 Gridelli C, Rossi A, Carbone DP, Guarize J, Karachaliou N, Mok T, Petrella F, Spaggiari L and Rosell R: Non small cell lung cancer. Nature Rev Dis Primers 1: 1-16, 2015.

3 Giaccone G: Epidermal growth factor receptor inhibitors in the treatment of non-small-cell lung cancer. J Clin Oncol 23: 32353242, 2005.

4 Gridelli C, de Marinis F, Cappuzzo F, Di Maio M, Hirsch F, Mok T, Morgillo F, Rosell R, Spigel D, Yang J and Ciardiello F: Treatment of advanced non small cell lung cancer with epidermal growth factor receptor $(E G F R)$ mutation or $A L K$ gene rearrangement: results of an International Expert Panel Meeting of the Italian Association of Thoracic Oncology. Clin Lung Cancer 15: 173-181, 2014.

5 Pao W and Chmielecki J: Rational, biologically based treatment of EGFR-mutant non-small-cell lung cancer. Nat Rev Cancer 10: 760-774, 2010

6 Lynch TJ, Bell DW, Sordella R, Gurubhagavatula S, Okimoto RA, Brannigan BW, Harris PL, Haserlat SM, Supko JG, Haluska FG, Louis DN, Christiani DC, Settleman J and Haber DA: Activating mutations in the epidermal growth factor receptor underlying responsiveness of non-small-cell lung cancer to gefitinib. N Engl J Med 350(21): 2129-2139, 2004.

7 Maione P, Sacco PC, Sgambato A, Casaluce F, Rossi A and Gridelli C: Overcoming resistance to targeted therapies in NSCLC: current approaches and clinical application. Ther Adv Med Oncol 7: 263-273, 2015.

8 Cross DA, Ashton SE, Ghiorghiu S, Eberlein C, Nebhan CA, Spitzler PJ, Orme JP, Finlay MR, Ward RA, Mellor MJ, Hughes G, Rahi A, Jacobs VN, Red Brewer M, Ichihara E, Sun J, Jin H, Ballard P, Al-Kadhimi K, Rowlinson R, Klinowska T, Richmond GH, Cantarini M, Kim DW, Ranson MR and Pao W: AZD9291, an irreversible EGFR TKI, overcomes T790M-mediated resistance to EGFR inhibitors in lung cancer. Cancer Discov 4(9): 1046-1061, 2014.

9 Jänne PA, Yang JC, Kim DW, Planchard D, Ohe Y, Ramalingam SS, Ahn MJ, Kim SW, Su WC, Horn L, Haggstrom D, Felip E, Kim JH, Frewer P, Cantarini M, Brown KH, Dickinson PA, Ghiorghiu S and Ranson M: AZD9291 in EGFR inhibitorresistant non small-cell lung cancer. N Engl J Med 372(18): 1689-1699, 2015. 
10 Neergheen VS, Bahorun T, Taylor EW, Jen LS and Aruoma OI: Targeting specific cell signaling transduction pathways by dietary and medicinal phytochemicals in cancer chemoprevention. Toxicology 278(2): 229-241, 2010.

11 Mazur WM, Duke JA, Wähälä K, Rasku S and Adlercreutz H: Isoflavonoids and Lignans in legumes: nutritional and health aspects in humans. J Nutr Biochem 9: 193-200, 1998.

12 Sarkar FH and Li Y: Mechanisms of cancer chemoprevention by soy isoflavone genistein. Cancer Metastasis Rev 21: 265-280, 2002.

13 Ravindranath MH, Muthugounder S, Presser N, Viswanathan S: Anticancer therapeutic potential of soy isoflavone, genistein. Adv Exp Med Biol 546: 121-165, 2004.

14 Chiang WD, Shih CJ and Chu YH: Optimization of acid hydrolysis conditions for total isoflavones analysis in soybean hypocotyls by using RSM. Food Chem 72: 499-503, 2001.

15 Rostagno MA, Palma M and Barroso CG: Ultrasound-assisted extraction of soy isoflavones. J Chromatogr A 1012(2): 119-128, 2003.

16 Amin I and Mukhrizah F: Antioxidant capacity of methanolic and water extracts prepared from food-processing by-products. J Sci Food Agric 86: 778-784, 2006.

$17 \mathrm{Xu}$ BJ and Chang SK: A comparative study on phenolic profiles and antioxidant activities of legumes as affected by extraction solvents. J Food Sci 72(2): S159-166, 2007.

18 Singleton VL and Rossi AR Jr.: Colorimetry of total phenolics with phosphomolybdic-phosphotungstic acid reagents. Am J Enol Vitic 16(3): 144-158, 1965.

19 Heimler D, Vignolini P, Dini MG and Romani A: Rapid tests to assess the antioxidant activity of Phaseolus vulgaris L. dry beans. J Agric Food Chem 53(8): 3053-3056, 2005.

20 Hansen MB, Nielsen SE and Berg K: Re-examination and further development of a precise and rapid dye method for measuring cell growth/cell kill. J Immunol Methods 119: 203210, 1989.

21 Coward L, Smith M, Kirk M and Barnes S: Chemical modification of isoflavones in soyfoods during cooking and processing Am. J Clin Nutr 68: 1486S-1491S, 1998.

22 Song T, Barua K, Buseman G and Murphy PA: Soy isoflavone analysis: quality control and a new internal standard. Am J Clin Nut 68: 1474S-1479S, 1998.

23 Nestel PJ, Pomeroy S, Kay S, Komesaroff P, Behrsing J, Cameron JD and West L: Isoflavones from red clover improve systemic arterial compliance but not plasma lipids in menopausal women J Clin Endocrinol Metab 84: 895-898, 1999.

24 Saviranta NM, Julkunen-Tiitto R, Oksanen E and Karjalainen RO: Red clover (Trifolium pratense L.) isoflavones: root phenolic Isoflavones and breast cancer compounds affected by biotic and abiotic stress factors. J Sci Food Agric 90: 418-423, 2010.
25 Booth NL, Piersen CE, Banuvar S, Geller SE, Shulman LP and Farnsworth NR: Clinical studies of red clover (Trifolium pratense) dietary supplements in menopause: a literature review. Menopause 13(2): 251-264, 2006.

26 Saviranta NM, Julkunen-Tiitto R, Oksanen E and Karjalainen RO: Leaf phenolic compounds in red clover (Trifolium pratense L.) induced by exposure to moderately elevated ozone. Environ Pollut 158: 440-446, 2010.

27 Booth NL, Overk CR, Yao P, Totura S, Deng Y and Hedayat AS, Bolton JL, Pauli GF, Farnsworth NR: Seasonal variation of red clover (Trifolium pratense L., Fabaceae) isoflavones and estrogenic activity. J Agric Food Chem 54(4): 1277-1282, 2006.

28 Marinova EM and Yanishlieva NV: Antioxidant activity of extracts from selected species of the family Laminaceae in sunflower oil. Food Chem 58: 245-248, 1997.

29 Kratchanova M, Denev P, Ciz M, Lojek A and Mihailov A: Evaluation of antioxidant activity of medicinal plants containing polyphenol compounds. Comparison of two extraction systems. Acta Biochim Pol 57: 229-234, 2010.

30 Ghasemzadeh A, Jaafar HZE and Rahmat A: Effects of solvent type on phenolics and flavonoids content and antioxidant activities in two varieties of young ginger (Zingiber officinale Roscoe) extracts. J Med Plants Res 5: 1147-1154, 2011.

31 Zitka O, Sochor J, Rop O, Skalickova S, Sobrova P, Zehnalek J, Beklova M, Krska B, Adam V and Kizek R: Comparison of various easy-to-use procedures for extraction of phenols from apricot fruits. Molecules 16: 2914-2936, 2011.

32 Hudalla CJ and Fountain KJ: Determination of Soy Isoflavones in Foods and Dietary Supplements by UPLC. Waters Corporation, Milford, MA, USA, 2012. Available at http:// www.waters.com/webassets/cms/library/docs/720004253en.pdf

$33 \mathrm{Wu}$ Q, Wang M and Simon JE: Determination of isoflavones in red clover and relate species by high-performance liquid chromatography combined with ultraviolet and mass spectrometric detection, J Chromatogr A 1016: 195-209, 2003.

34 De Rijke E, Zafra-Gómez A, Ariese F, Brinkman UA and Gooije C: Determination of isoflavone glucoside malonates in Trifolium pratense L. (red clover) extracts: quantification and stability studies, J Chromatogr A 932(1-2): 55-64, 2001.

Received August 7, 2016

Revised September 5, 2016

Accepted September 12, 2016 